Original Article

\title{
COMPARATIVE STUDY ON THE ANTIOXIDANT ACTIVITIES OF METHANOLIC AND AQUEOUS EXTRACTS OF TERMINALIA BELLERICA
}

\author{
RASNA GUPTA1 ${ }^{1}$ RAM LAKHAN SINGH' ${ }^{1}$, ANKIT GUPTA $^{2}$ \\ ${ }^{1}$ Department of Biochemistry, Dr. Ram Manohar Lohia Avadh University, Faizabad 224001, India, ${ }^{2}$ Department of Biochemistry, All India \\ Institute of Medical Sciences (AIIMS), Raebareli 229405, India \\ Email: rasna.gupta.biochem@gmail.com \\ Received: 10 Aug 2019, Revised and Accepted: 12 Oct 2019
}

\begin{abstract}
Objective: The present study was undertaken to investigate the antioxidative activity of fruit pulp, seed and bark of T. bellerica.

Methods: Methanol (70\%) and water were used for the extraction, and the respective extracts were analyzed for total phenolic contents along with the antioxidant activities through different assays.

Results: Amongst the tested extracts, methanolic extracts were found to be better than aqueous with the highest total phenolic contents (TPC) Methanolic fruit pulp showed lower IC 50 for free radical $(118.7 \mu \mathrm{g} / \mathrm{ml})$, superoxide anion radical $(77.65 \mu \mathrm{g} / \mathrm{ml})$ and hydroxyl radical $(73.76 \mu \mathrm{g} / \mathrm{ml})$ scavenging activities. Methanolic fruit pulp also showed lower IC 50 for lipid peroxidation $(115.6 \mu \mathrm{g} / \mathrm{ml})$ and ferric thiocyanate $(184.98 \mu \mathrm{g} / \mathrm{ml})$ assay than aqueous extracts in comparison to standard quercetin. Further, correlation between TPC and antioxidant studies revealed that phenolics are mainly responsible for antioxidant activity of $T$. bellerica.
\end{abstract}

Conclusion: The current study suggests that the methanolic extract of $T$. bellerica could be a potential source of natural antioxidants for food and pharmaceutical companies.

Keywords: Reactive oxygen species, Total phenolic content, Antioxidant, Terminalia. Bellerica

(C) 2019 The Authors. Published by Innovare Academic Sciences Pvt Ltd. This is an open access article under the CC BY license (http://creativecommons.org/licenses/by/4.0/) DOI: http://dx.doi.org/10.22159/ijcpr.2019v11i6.36354

\section{INTRODUCTION}

Reactive oxygen species (ROS) can cause severe damage to the normal cells of the body. This damage can be to the DNA, proteins and other macromolecules. Oxidative stress, caused by an imbalance between antioxidant systems and the production of oxidants (ROS), seems to be associated with many multifactorial diseases especially cancers, cardiovascular diseases and inflammatory disorders $[1,2]$. The increase in ROS generation or decreased antioxidant availability can result in a net increase in intracellular oxidative damage. The mechanism of action of many synthetic antioxidants involves free radical (FR) scavenging property, which protects against oxidative damage but has adverse side effects [3]. The synthetic antioxidant may cause cellular toxicity; however, there is an alternative is the consumption of natural antioxidants from various food supplements and traditional medicines [4]. There is increased interest among phytotherapy researchers to use medicinal plants with antioxidant activity for protection against oxidative stress.

Terminalia bellerica (TB) Roxb (Combretaceae), is a large deciduous tree found throughout India that reaches height up to 30 meters. Trunk of the tree is straight with brownish-grey color. Leaves are long, alternate, oval and are clustered towards the end of branches. These are 7-14 cm in breadth and $10-12 \mathrm{~cm}$ in length. Simple and solitary flowers are white or yellow in color and appear in the month of May. Fruits are ovoid in shape and appear grey in color. TB has been valued in Ayurvedic and traditional systems of medicine for treatment of wide range of diseases having many pharmacological properties such as anti-inflammatory, immunomodulatory, anticancer, hepatoprotective and antimicrobial [5-9]. It is an integral part of ancient formulation, Triphala which is used for a variety of ailments in Ayurveda. GC-MS analysis revealed that TB contains various polyphenolic and other bioactive compounds such as gallic acid, quinic acid (chlorogenic acid), ethyl galate, 9,12 octadecadienoic acid, glucopyranose, sitosterol, protein, tannins, galactose, glucose, mannitol, fructose, ramnose etc [10]. Antioxidant activities increase proportionally with the polyphenol content, primarily because of their redox properties. Among the diverse roles of polyphenols, they protect cell constituents against destructive oxidative damage, thus limiting the risk of various degenerative diseases associated with oxidative stress by acting as potent FR scavengers [11]. Recent studies focused on the comparison of antioxidant activities of methanolic and aqueous extracts of TB and their correlation with total phenolic content.

\section{MATERIALS AND METHODS}

\section{Plant materials}

Plant materials were collected from herbal garden of Narendra Dev University of Agriculture and Technology Kumarganj, Faizabad, U. P., India and identified with the help of Dr. MN Srivastava, Senior Scientist, Botany Division, CSIR-Central Drug Research Institute, Lucknow, India and the voucher specimens (2322 CSIR-CDRI) were submitted in CDRI herbarium.

\section{Chemicals and reagents}

Quercetin, gallic acid, 1, 1-diphenyl-2-picrylhydrazyl (DPPH) and thiobarbituric acid (TBA) were purchased from Sigma-Aldrich, St. Louis, USA. Ascorbic acid, Folin Ciocalteau's phenol reagents were the product of E. Merk, Mumbai, India. Nitro blue tetrazolium (NBT), phenazine methosulphate (PMS), reduced nicotinamide adenine dinucleotide (NADH), potassium ferricyanide, trichloroacetic acid (TCA), ferric chloride $\left(\mathrm{FeCl}_{3}\right)$, ferrous sulphate $\left(\mathrm{FeSO}_{4}\right)$ and sodium dodecyl sulphate (SDS) were purchased from SRL India. All other reagents and chemicals used were of analytical grade.

\section{Extraction procedure}

Twenty grams of the dried and powdered plant sample of TB fruit pulp, seed and bark was extracted with $70 \%$ methanolic solvent (in distilled water) and aqueous system for overnight at room temperature in an orbital shaker. The methanolic fruit pulp (MEFP), seed (MES), bark (MEB) and aqueous fruit pulp (AQFP), seed (AQS) bark (AQB) extracts were separated from the residues by filtering through Whatman No. 1 filter paper. The residues were extracted until decoloration with the same fresh solvent and extracts 
combined. The combined extracts were concentrated and freed of solvent under reduced pressure at $40{ }^{\circ} \mathrm{C}$ by using a rotary evaporator and lyophilized till dryness. The dried crude concentrated extracts were stored at- $4{ }^{\circ} \mathrm{C}$ and used for the antioxidant activity determination.

\section{Antioxidant studies \\ Total phenolic content (TPC)}

TPC of powdered plant material was extracted with 50\% methanol $+1 \% \mathrm{HCl}$, filtered and made up to $10 \mathrm{ml}$ each with water. TPC was measured with the method of Ragazzi and Veronese [12]. To $0.1 \mathrm{ml}$ plant extract, $0.5 \mathrm{ml}$ of Folin's reagent $(1 \mathrm{~N})$ and $1.0 \mathrm{ml}$ of $\mathrm{Na}_{2} \mathrm{CO}_{3}$ were added subsequently. The test mixture was mixed properly and kept at room temperature for $30 \mathrm{~min}$ and volume was made up to $12.5 \mathrm{ml}$ with distilled water. The absorbance of this solution was measured at $720 \mathrm{~nm}$. The TPC was reported as mg of gallic acid equivalent (GAE)/g of dry weight.

\section{Free radical scavenging activity (FRSA)}

FRSA of the extracts was measured by using DPPH stable radical according to the method of Yen and Duh [13]. Each extract $(0.1 \mathrm{ml})$ was added to a freshly prepared DPPH solution $\left(6 \times 10^{-5} \mathrm{M}\right.$ in HPLC grade $2.9 \mathrm{ml}$ methanol) and mixed vigorously. The reduction of the DPPH radical ( $\mathrm{DPPH}^{\circ}$ ) was measured by continuous monitoring of the decrease in absorbance at $515 \mathrm{~nm}$ until a stable value was obtained.

\section{Inhibition (\%) $=[($ blank absorbance-sample absorbance $) /$ blank} absorbance] $\times 100$

The inhibitory concentration ( $\mathrm{IC}_{50}$ ), which represents the amount of antioxidant necessary to decrease the initial DPPH concentration by $50 \%$, representing a parameter widely used to measure the antioxidant activity, was calculated from a calibration curve by linear regression. $\mathrm{EC}_{50}$ was calculated as $\mathrm{IC}_{50}(\mu \mathrm{g} / \mathrm{ml}) /$ concentration of $\mathrm{DPPH} / \mathrm{ml}$ and expressed as $\mu \mathrm{g} / \mathrm{mg}$ DPPH. For rational reasons of clarity, the ARP was determined as the reciprocal value of the $\mathrm{EC}_{50}$, representing a comparable term for the effectiveness of antioxidant and radical scavenging capacity:

$$
\mathrm{ARP}=1 / \mathrm{EC}_{50} \times 100
$$

The larger the ARP, the more efficient the antioxidant

\section{Superoxide anion radical scavenging activity (SARSA)}

This assay was based on the capacity of the extract to inhibit the reduction of nitro blue tetrazolium (NBT) by the method of Nishikimi et al. [14]. Three milliliters reaction mixture containing different aliquot of plant extracts $(50,100,150$ and $200 \mu \mathrm{l})$ with 0.1 M phosphate buffer (pH 7.8), $60 \mu \mathrm{M}$ PMS, $468 \mu \mathrm{M}$ nicotinamide adenine dinucleotide reduced (NADH) and $150 \mu \mathrm{M}$ NBT was incubated for $5 \mathrm{~min}$ at ambient temperature. Absorbance was read after $6 \mathrm{~min}$ at $560 \mathrm{~nm}$ using a UV-Vis spectrophotometer. The percentage inhibition (PI) of superoxide $\left(\mathrm{O}_{2}{ }^{*}\right)$ generation was measured by comparing the absorbance of the control and those of the reaction mixture containing the test sample.

\section{Reducing power (RP)}

RP of the extracts was determined by using a slightly modified method of ferric reducing-antioxidant power assay [15]. Each extract (1.0 ml) was mixed with $2.5 \mathrm{ml}$ of phosphate buffer $(0.1 \mathrm{M}, \mathrm{pH} 6.6)$ and $2.5 \mathrm{ml}$ of $1 \%(\mathrm{w} / \mathrm{v})$ potassium ferricyanide and was incubated at $50^{\circ} \mathrm{C}$ for 20 min. After completion of the incubation period, $2.5 \mathrm{ml}$ of $10 \%(\mathrm{w} / \mathrm{v})$ trichloroacetic acid (TCA) was added to terminate the reaction. The upper layer $(2.5 \mathrm{ml})$ was diluted with an equal volume of deionized water. Finally, $0.5 \mathrm{ml}$ of $0.1 \%$ (w/v) $\mathrm{FeCl}_{3}$ was added and after $10 \mathrm{~min}$ the absorbance was measured at $700 \mathrm{~nm}$ against a blank. RP was expressed as ascorbic acid equivalents ( $1 \mathrm{ASE}=1 \mathrm{mmol}$ ascorbic acid). ASE value is inversely proportional to RP.

\section{Lipid peroxidation (LPO)}

A modified thiobarbituric acid-reactive species (TBARS) assay method of Ohkawa et al. [16]. was applied to measure the LPO formation, using egg homogenate as lipid-rich media. Egg homogenate $(10 \%$ in $0.2 \mathrm{M} \mathrm{PBS}, 0.5 \mathrm{ml})$, test extract $(0.1 \mathrm{ml})$ and $\mathrm{DW}$
$(0.85 \mathrm{ml})$ were mixed in a test tube. Finally, $\mathrm{FeSO}_{4}(0.07 \mathrm{M}, 0.05 \mathrm{ml})$ was added to the reaction mixture and incubated at $37{ }^{\circ} \mathrm{C}$ temperature for $30 \mathrm{~min}$ to induce LPO. Thereafter, acetic acid (20\%, $1.5 \mathrm{ml})$, TBA $(0.8 \%$ prepared in $1.1 \%$ SDS, $1.5 \mathrm{ml})$ and TCA $(20 \%$, $0.05 \mathrm{ml}$ ) was added, vortexed and then heated in a boiling water bath for $60 \mathrm{~min}$. After cooling, butanol $(5 \mathrm{ml})$ was added to each tube and centrifuged for $10 \mathrm{~min}$ at $3000 \mathrm{rpm}$. The absorbance of the upper organic layer was measured at $532 \mathrm{~nm}$ by UV-Vis spectrophotometer (Labtronics, model LT-2910).

\section{Hydroxyl radical scavenging activity (HRSA)}

$\mathrm{OH} \cdot$ were generated by a mixture of $\mathrm{Fe}^{3+}$-EDTA, $\mathrm{H}_{2} \mathrm{O}_{2}$ and ascorbic acid and assessed by monitoring the degraded fragments of deoxyribose, through malondialdehyde (MDA) formation [17]. The reaction mixtures contained ascorbic acid $(50 \mu \mathrm{M}), \mathrm{FeCl}_{3}(20 \mu \mathrm{M})$, EDTA $(2 \mathrm{mmol}), \mathrm{H}_{2} \mathrm{O}_{2}(1.42 \mathrm{mmol})$, deoxyribose $(2.8 \mathrm{mmol})$ with different concentrations of the plant extracts in a final volume of 1 $\mathrm{ml}$, was incubated at $37^{\circ} \mathrm{C}$ for 1 hour and then $1 \mathrm{ml}$ of $2.8 \%$ TCA (w/v in water) and $1 \mathrm{ml}$ of $1 \%$ TBA (w/v) were added. The mixture was heated in a boiling water bath for $30 \mathrm{~min}$. It was cooled and absorbance was taken at $532 \mathrm{~nm}$.

\section{Ferric thiocyanate assay (FTC)}

The reaction mixture containing $400 \mu$ of different concentration of ethanolic plant extracts, $200 \mu \mathrm{l}$ of diluted linoleic acid $(25 \mathrm{mg} / \mathrm{ml}$ in $99 \%$ ethanol) and $400 \mu \mathrm{l}$ of $50 \mathrm{mmol}$ phosphate buffer ( $\mathrm{pH}$ 7.4) was incubated for $15 \mathrm{~min}$ at $40{ }^{\circ} \mathrm{C}$. A $100 \mu \mathrm{l}$ aliquot of this was then mixed with a reaction mixture containing $3 \mathrm{ml}$ of $70 \%$ ethanol, 100 $\mu \mathrm{l}$ of ammonium thiocyanate $(300 \mathrm{mg} / \mathrm{ml}$ in DW) and $100 \mu \mathrm{l}$ of ferrous sulphate. Red color developed was measured at $535 \mathrm{~nm}$ [18].

\section{Statistical analysis}

All analytical data are subjected to an analysis of variance (ANOVA). Each value is a mean \pm standard deviation (SD) of three replications $(n=3)$. Statistical analysis was conducted by using prism software (graph pad prism software version 3.0, USA). The results obtained were considered statistically significant if $p<0.05$. The $R^{2}$ value and the regression equation were calculated by plotting a graph showing the TPC on the x-axis and the antioxidant deciding parameters on the y-axis, using MS office excel 2007.

\section{RESULTS}

\section{Total phenolic content (TPC)}

The TPC in methanolic and aqueous extracts of TB ranged from 98.68 to $127.60 \mathrm{mg} / \mathrm{g} \mathrm{GAE}$ and 56.97 to $80.11 \mathrm{mg} / \mathrm{g} \mathrm{GAE}$ (fig. 1). The highest value of TPC was present in MEFP $(127.60 \mathrm{mg} / \mathrm{g} \mathrm{GAE})$ followed by MES (108.58 mg/g GAE) and MEB (98.68 mg/g GAE) which signifies its high antioxidant activity than aqueous extracts.

\section{Free radical scavenging activity (FRSA)}

Methanolic and aqueous extracts of TB were examined for their potential to scavenge FRs and measured as PI. Methanolic extracts were considered to be the most potent significant FR scavenger than aqueous extracts and its value of inhibition ranged from 62.95 to $68.34 \%$ (fig. 2). FRSA values of methanolic extracts were in following order MES (68.34\%)>MEFP (68.34\%)>MEB (62.95\%) while in aqueous extracts the order was AQS (53.82\%)>AQB (53.50)>AQFP (51.58\%). Thus methanolic extracts showed high FRSA than aqueous in comparison to standard quercetin (90.25\%). The $\mathrm{IC}_{50}$ value of MEFP was $118.7 \mu \mathrm{g} / \mathrm{ml}$, whereas, in the case of MES and MEB, it was 130 and $146.7 \mu \mathrm{g} / \mathrm{ml}$, respectively.

\section{Superoxide anion radical scavenging activity (SARSA)}

The antioxidant potential of methanolic extracts against $\mathrm{O}_{2} \cdot$ was considered to be significant in comparison to the standard quercetin. The result presented in fig. 3 shows that methanolic extracts inhibits NBT reduction significantly high than aqueous extracts. The order of SARSA of methanolic and aqueous extracts were MEFP $(75.86 \%)>\operatorname{MEB}(73.86 \%)>\operatorname{MES}(72.99 \%)$ and AQFP $(62.91 \%)>A Q S(56.82 \%)>A Q B(56.19)$ in comparison to standard quercetin $(91.77 \%)$ at $200 \mu \mathrm{g} / \mathrm{ml}$ concentration. The $\mathrm{IC}_{50}$ value at which methanolic extracts showed significant SARSA was 77.65 (MEFP), 155.53 (MEB) and 191.75 (MES) $\mu \mathrm{g} / \mathrm{ml}$. 


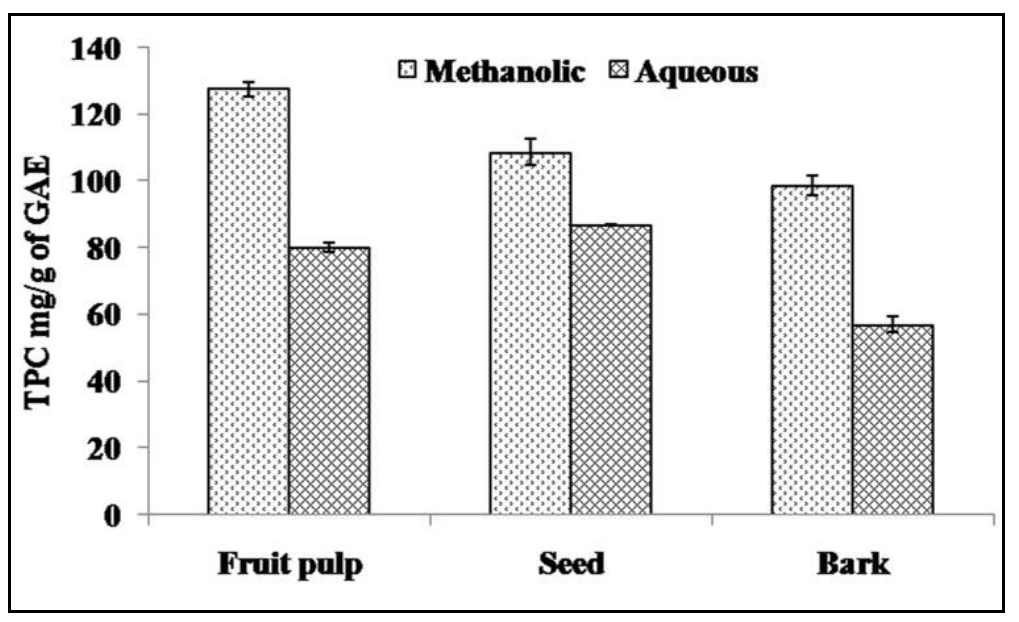

Fig. 1: Total phenolic content of methanolic and aqueous extracts of $T$. bellerica. Values are mean \pm SD of three replications (n=3). MEFP: methanolic fruit pulp; MES: methanolic seed; MEB: methanolic bark; AQFP: aqueous fruit pulp; AQS: aqueous seed; AQB: aqueous bark

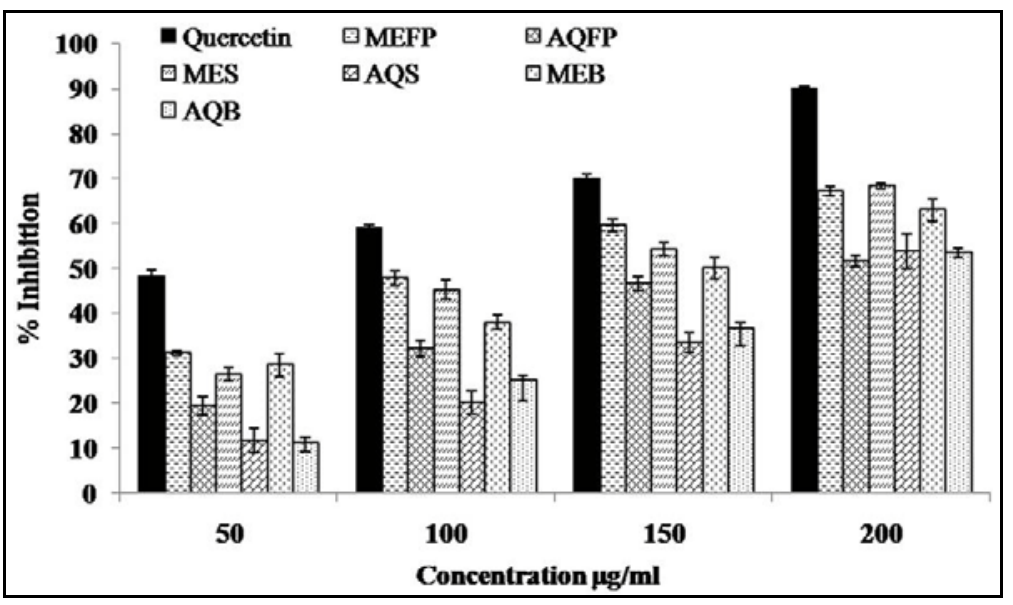

Fig. 2: Free radical scavenging activity of methanolic and aqueous extracts of $T$. bellerica and standard quercetin against DPPH radicals at varying concentrations. Values are mean \pm SD of three replications $(n=3)$. MEFP: methanolic fruit pulp; MES: methanolic seed; MEB: methanolic bark; AQFP: aqueous fruit pulp; AQS: aqueous seed; AQB: aqueous bark

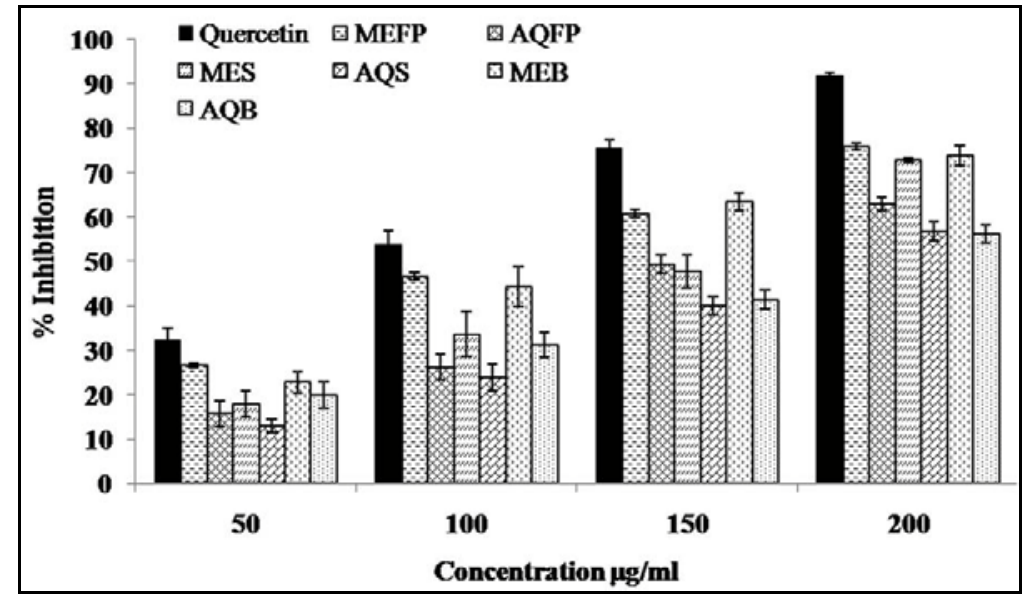

Fig. 3: Inhibitory effects of methanolic and aqueous extracts of $T$. bellerica and standard quercetin on superoxide anion radical at varying concentrations. Values are mean \pm SD of three replications $(n=3)$. MEFP: methanolic fruit pulp; MES: methanolic seed; MEB: methanolic bark; AQFP: aqueous fruit pulp; AQS: aqueous seed; AQB: aqueous bark

Lipid peroxidation (LPO)

Studies on the inhibition of LPO in the presence of extracts were carried out and expressed as PI. The methanolic and aqueous extracts prevent LPO induced by FeSO4 and PI varied from 63.02 to $71.51 \%$ and 54.40 to $60.75 \%$, respectively. Maximum LPO inhibition was shown by MEFP (71.51\%) than MES (64.70\%) and MEB $(63.02 \%)$ in a concentration-dependent manner at $100-400 \mu \mathrm{g} / \mathrm{ml}$ in 
comparison to standard (95.39\%). Methanolic extracts showed antiLPO activity at lower IC 50 value 115.6 (MEFP), 130.3 (MES) and
144.5 (MEB) $\mu \mathrm{g} / \mathrm{ml}$ (fig. 4) in comparison to aqueous extracts 290 (AQFP), 300 (AQS) and 331 (AQB) $\mu \mathrm{g} / \mathrm{ml}$.

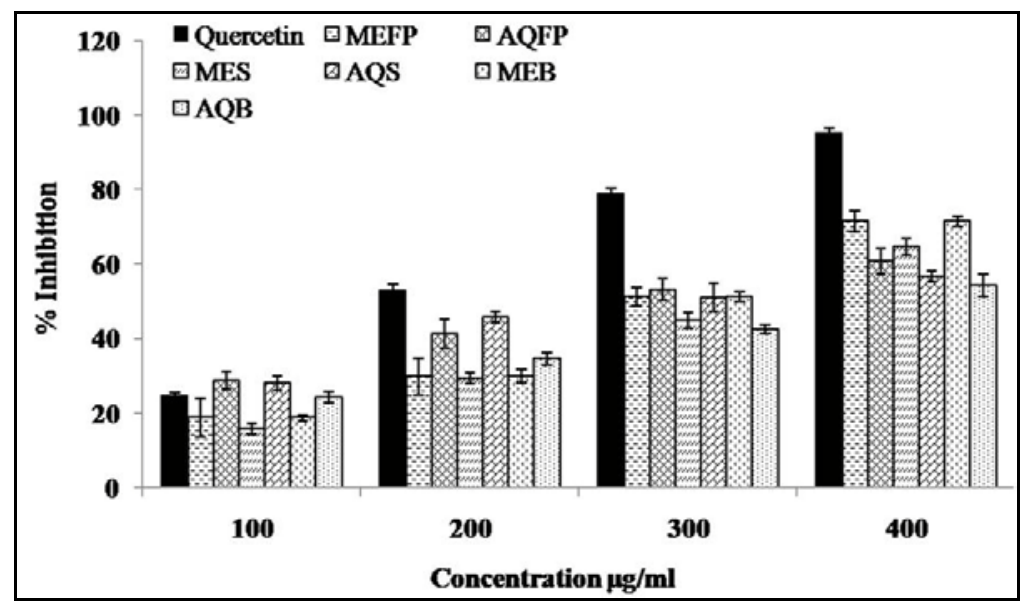

Fig. 4: Inhibitory effects of methanolic and aqueous extracts of $T$. bellerica and standard quercetin on LPO using egg homogenate as a lipid-rich source at varying concentrations. Values are mean \pm SD of three replications $(n=3)$. MEFP: methanolic fruit pulp; MES: methanolic seed; MEB: methanolic bark; AQFP: aqueous fruit pulp; AQS: aqueous seed; AQB: aqueous bark

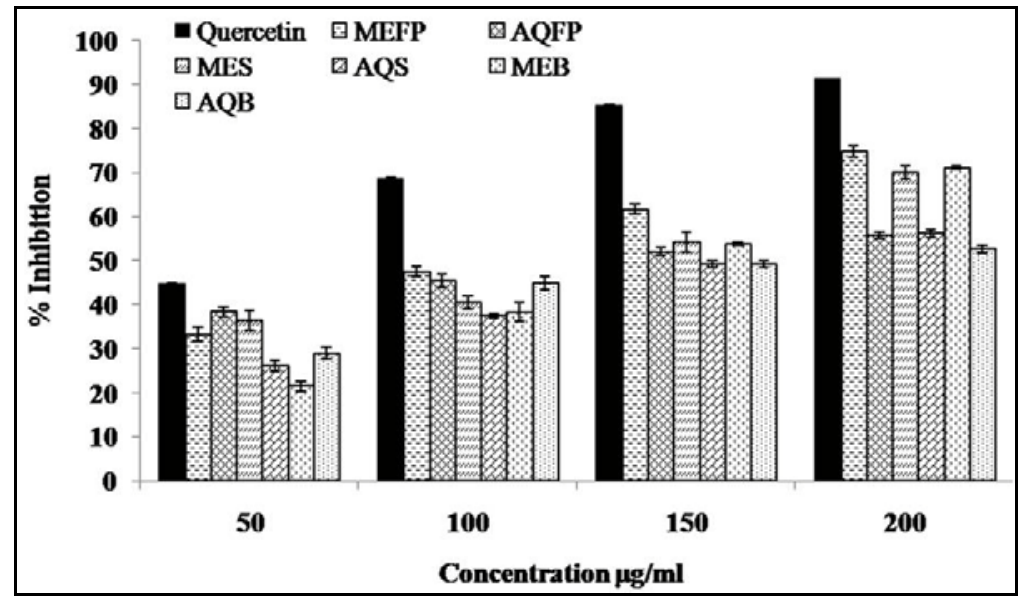

Fig. 5: Inhibitory effects of methanolic and aqueous extracts of $T$. bellerica and standard quercetin on hydroxyl radical-mediated deoxyribose degradation at varying concentrations. Values are mean \pm SD of three replications $(n=3)$. MEFP: methanolic fruit pulp; MES methanolic seed; MEB: methanolic bark; AQFP: aqueous fruit pulp; AQS: aqueous seed; AQB: aqueous bark

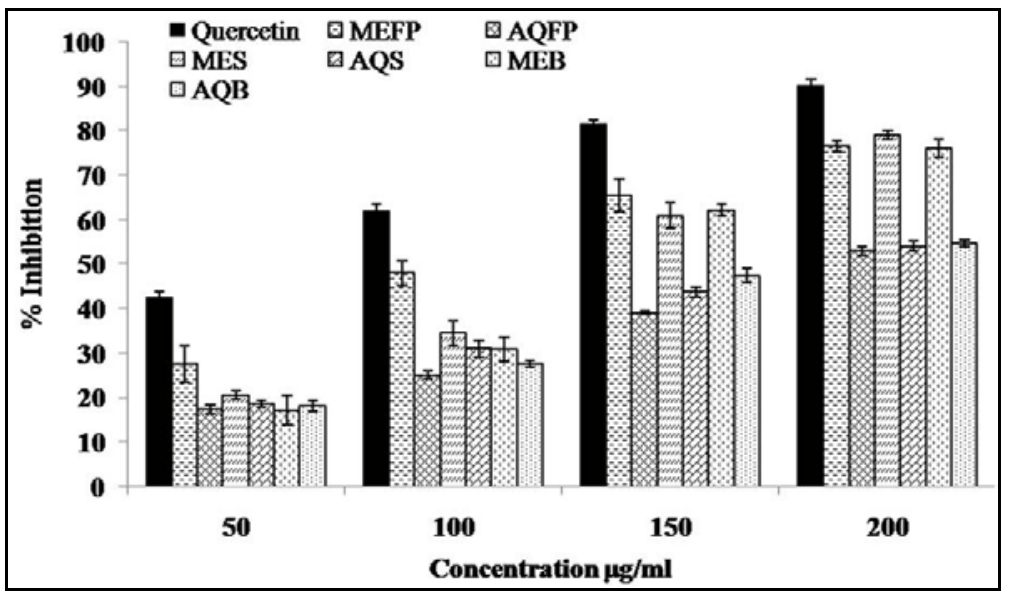

Fig. 6: Inhibitory effects of methanolic and aqueous extract of $T$. bellerica and standard quercetin on ferric ion chelation by ferric thiocyanate assay method at varying concentrations. Values are mean \pm SD of three replications $(n=3)$. MEFP: methanolic fruit pulp; MES: methanolic seed; MEB: methanolic bark; AQFP: aqueous fruit pulp; AQS: aqueous seed; AQB: aqueous bark 


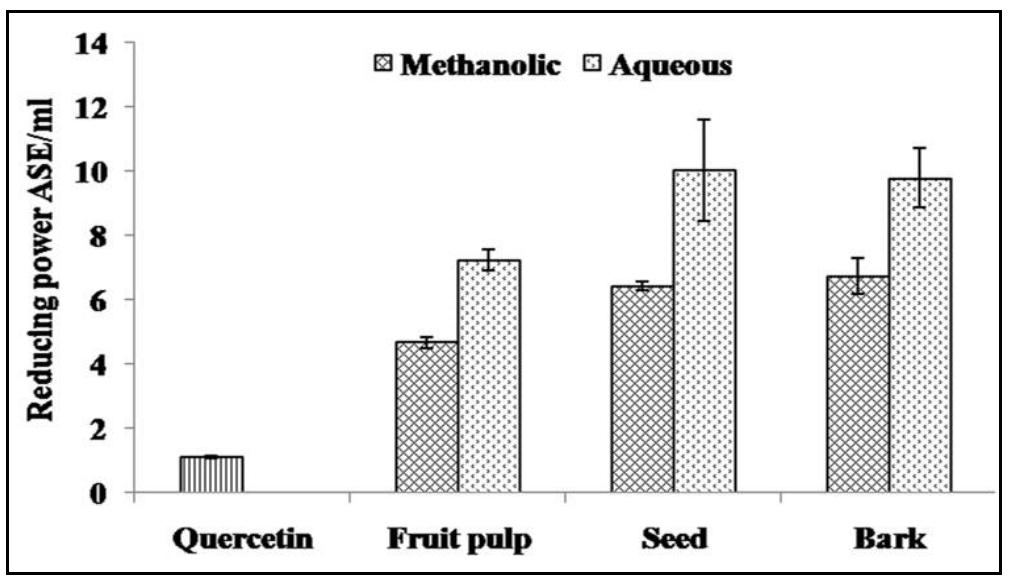

Fig. 7: Reducing power (ASE/ml) of methanolic and aqueous extracts of $T$. bellerica and standard quercetin. Values are mean \pm SD of three replications (n=3). MEFP: methanolic fruit pulp; MES: methanolic seed; MEB: methanolic bark; AQFP: aqueous fruit pulp; AQS: aqueous seed; AQB: aqueous bark

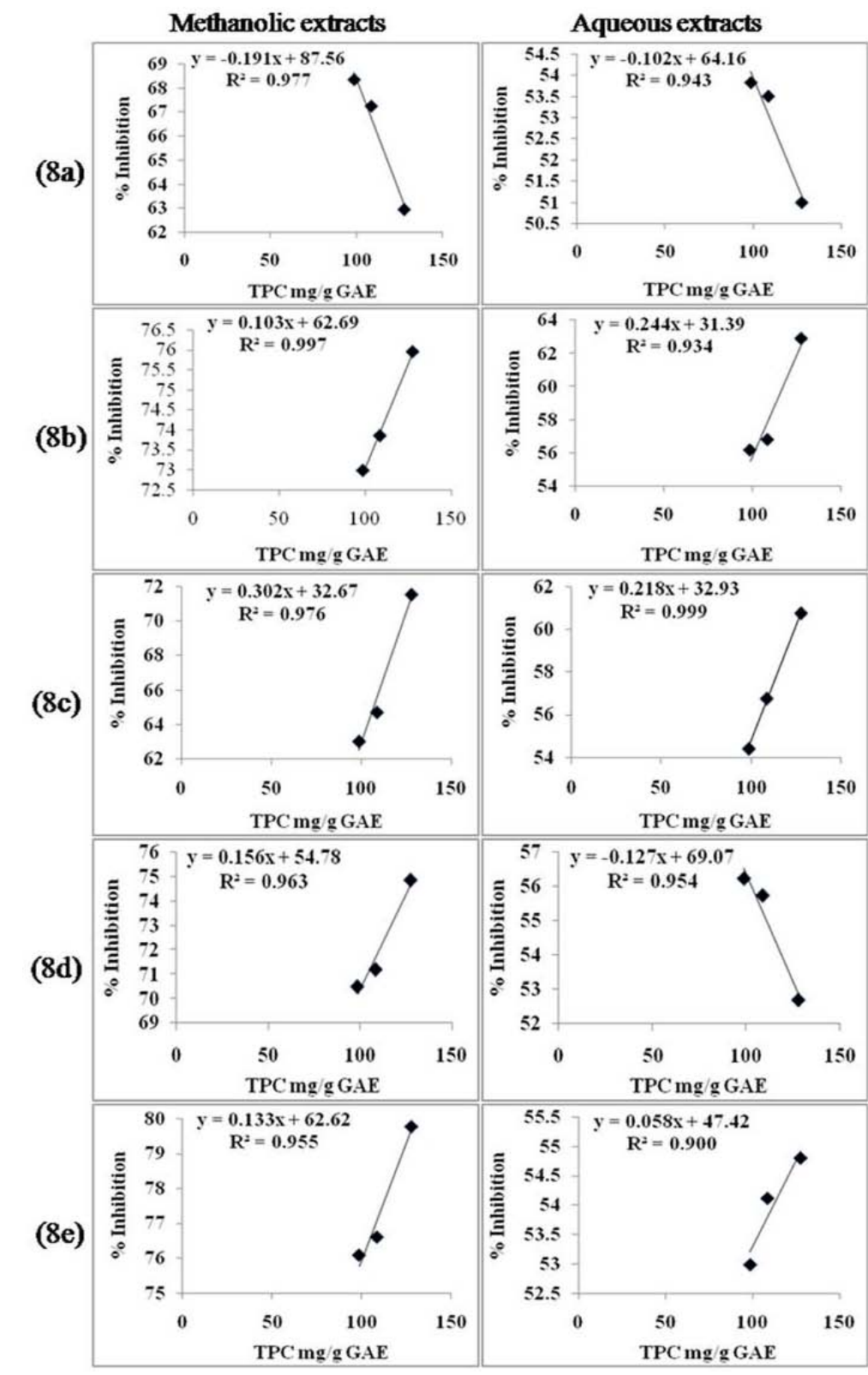

Fig. 8: Linear correlation between TPC ( $x$ axis) in the plant extracts in relation to their antioxidant activity ( $y$ axis). (8a) TPC versus FRSA (8b) TPC versus SARSA (8c) TPC versus LPO (8d) TPC versus HRSA (8e) TPC versus FTC assay 


\section{Hydroxyl radical scavenging activity (HRSA)}

Methanolic and aqueous extracts were further studied for their ability to chelate iron and/or to scavenge $\mathrm{OH}^{\bullet}$ by using deoxyribose degradation assay. The methanolic extracts were found to be most potent $\mathrm{OH}^{\cdot}$ scavenger with inhibition of 70.51 to $74.86 \%$ than aqueous extracts of $52.70 \%$ to $56.23 \%$ in comparison with quercetin (91.12\%) (fig. 5). The biochemical studies revealed that methanolic extracts caused a concentration-dependent $(50-200 \mu \mathrm{g} / \mathrm{ml})$ inhibition of deoxyribose oxidation. The $\mathrm{IC}_{50}$ at which methanolic and aqueous extracts showed HRSA was 73.76 (MEFP), 81.99 (MES), 90.76 (MEB) $\mu \mathrm{g} / \mathrm{ml}$ and 425.9 (AQFP), 488.0 (AQS), 548.0 (AQB) $\mu \mathrm{g} / \mathrm{ml}$, respectively.

\section{Ferric thiocyanate (FTC)}

In tested extracts, methanolic extracts showed maximum inhibition (76.08\% to $79.78 \%)$ than aqueous extracts $(53.00 \%$ to $54.80 \%)$ to inhibit production of FRs which initiates oxidation of lipids and proteins. Quercetin showed $92.12 \%$ inhibition to inhibit the production of peroxides. The inhibition is increased with increasing concentration of the extracts from 50 to $200 \mu \mathrm{g} / \mathrm{ml}$ in the reaction mixture and the maximum inhibition was shown by MES (79.78\%) (fig. 6). The $\mathrm{IC}_{50}$ of methanolic extracts was in the range 184.98 (MEFP) $>212.5$ (MES) $>221.4$ (MEB).

\section{Reducing power (RP)}

The RP of a compound may act as a significant indicator of its potential antioxidant activity [19]. With regards to RP, higher reducing capacity might be attributed to the higher amount of phenolic compounds. Methanolic extracts had significantly high $\mathrm{Fe}^{3+}$ to $\mathrm{Fe}^{2+}$ transformation capacity $(6.73$ to $4.68 \mathrm{ASE} / \mathrm{ml})$ than aqueous extracts ( 10.03 to $7.25 \mathrm{ASE} / \mathrm{ml}$ ) in comparison to standard quercetin (1.12 ASE/ml) (fig. 7), showing high phenolic content in methanolic extracts.

\section{Correlation between antioxidant activities and TPC}

Phenolics are the major contributors to the antioxidant activity. The correlation between TPC and FRSA of methanolic and aqueous extracts had a correlation coefficient of $\mathrm{R}^{2}=0.977(\mathrm{y}=-0.191 \mathrm{x}+87.56)$ and $\mathrm{R}^{2}=$ $0.943(y=-0.102 x+64.16)$. A good correlation also exists between TPC and other antioxidant activities (fig. 8).

\section{DISCUSSION}

Phenolic compounds and polyphenols are the most abundant structures in plants. Antioxidant compounds are usually in the phenolic form. The antioxidant properties of phenolic compounds originate from their properties of proton loss, chelate formation and dismutation of radicals. In fact, in some studies, theoretical methods have been proposed to estimate the antioxidant activities of phenolic substances. Their structure-activity relationships are examined for this purpose. Phenols are compounds that have the ability to destroy radicals because they contain hydroxyl groups. These important plant components give up hydrogen atoms from their hydroxyl groups to radicals and form stable phenoxyl radicals; hence, they play an important role in antioxidant activity. Therefore, determination of the quantity of phenolic compounds is very important in order to determine the antioxidant capacity of plant extracts $[20,21]$. In fig. 1 , the quantity of TPC in methanolic and aqueous extracts of TB is shown. According to Shahriar et al. [22] and Venkatesan et al. [23] hexane and chloroform extract of Terminalia arjuna fruit ( 73.00 and $61.72 \mathrm{mg} / \mathrm{g}$ of GAE) and Terminalia chebula bark ( 28.68 and $62.68 \mathrm{mg} / \mathrm{g}$ of GAE) showed lower TPC in comparison to our reported values of methanolic extracts.

The DPPH method is a preferred method to determine FRSA because it is fast, easy and reliable and does not require a special reaction and device. DPPH is a stable, synthetic radical that does not disintegrate in water, methanol or ethanol. The FRSA of extracts depends on the ability of antioxidant compounds to lose hydrogen and the structural conformation of these components [24, 25]. The $\mathrm{DPPH}^{\circ}$, which is at its maximum wavelength at $517 \mathrm{~nm}$, can easily receive an electron or hydrogen from antioxidant molecules to become a stable diamagnetic molecule as DPPH-H. [26] Owing to the
$\mathrm{DPPH} \cdot$ ability to bind $\mathrm{H}$, it is considered to have a radical scavenging property. Discoloration occurs due to the decreasing quantity of DPPH -into reaction mixture which rlects the FRSA of the tested extract [27]. In fig. 2, FRSA of different concentrations of methanolic and aqueous extracts of $T$. bellerica are demonstrated. The antioxidant activities of the extracts were compared with quercetin, which is a known natural antioxidant. The radical scavenging effect of the methanolic extract was significant high in comparison to the aqueous extract.

$\mathrm{O}_{2}$ *are a precursor to active FRs that have the potential of reacting with biological macromolecules and thereby inducing tissue damage [28]. It has been implicated in several pathophysiological processes due to its transformation into more ROS such as $\mathrm{OH}^{\cdot}$ that initiates LPO. Also, $\mathrm{O}_{2} \cdot$ has been observed to directly initiate LPO [29]. $\mathrm{O}_{2} \cdot$-is normally formed first, and its effects can be magnified because it produces other kinds of FRs $\left(\mathrm{H}_{2} \mathrm{O}_{2}\right.$ and $\left.{ }^{1} \mathrm{O}_{2}\right)$ and oxidizing agents [30] which induce oxidative damage in lipids, proteins and DNA [31]. $\mathrm{O}_{2} \bullet$-derived from dissolved oxygen by PMS-NADH coupling reaction and reduces NBT in this system. In this method, $\mathrm{O}_{2}{ }^{-}$-reduces the yellow dye $\left(\mathrm{NBT}^{2+}\right)$ to produce the blue formazan which is measured spectrophotometrically at $560 \mathrm{~nm}$. Plant extracts that contain antioxidants are able to inhibit the blue NBT formation [32, 33]. The decrease of absorbance at $560 \mathrm{~nm}$ with antioxidants indicates the consumption of $\mathrm{O}_{2} \cdot$-in the reaction mixture. Fig. 3 clearly indicates that TB is a potent scavenger of $\mathrm{O}_{2}{ }^{\circ}$. According to Venkatesan et al. [23] methanolic extracts showed $\mathrm{O}_{2} \cdot$-inhibition at IC $_{50} 166.29 \mu \mathrm{g} / \mathrm{ml}$ which is almost equal to our reported value $155.53 \mu \mathrm{g} / \mathrm{ml}$.

In LPO assay, antioxidant potential is measured by evaluating the capability of test sample to hamper the oxidation of polyunsaturated fatty acids (PUFA) into TBARS. Peroxidation generates peroxyl radicals which decompose to MDA. It forms a stable product with TBA, which serve as a mean to quantify the level of peroxidation [34]. This assay is very useful mean to assess LPO in vitro due to its simplicity and reproducibility. According to Sherin et al. [35] hexane, chloroform and ethyl acetate extracts of TB leaf showed $50 \%$ inhibition at concentration $0.350,0.280,0.520 \mathrm{mg} / \mathrm{ml}$ which was much higher than our reported values of methanolic extracts.

The $\mathrm{OH}^{\bullet}$ can induce oxidative damage to DNA, lipids and proteins and are involved in various neurodegenerative and cardiovascular diseases [36]. The HRSA of the extracts was determined by its ability to compete with deoxyribose for $\mathrm{OH}^{\circ}$. In this assay, 2-deoxy-2-ribose was oxidized when exposed to $\mathrm{OH}^{\bullet}$ generated by the fenton-type reaction. The oxidative degradation can be detected by heating the products with TBA under acidic conditions to develop a pink chromogen with a maximum absorbance at $532 \mathrm{~nm}$ [37].

Inhibition of linoleic acid oxidation was also used to assess the antioxidant activity of the tested extracts. Antioxidant activity of different extracts was determined by inhibition of peroxidation in linoleic acid system using thiocyanate method [38]. Linoleic acid is a PUFA, upon oxidation peroxides are formed which oxidize $\mathrm{Fe}^{2+}$ to $\mathrm{Fe}^{3+}$, the later forms complex with thiocyanate ion (SCN-), concentration of which is determined spectrophotometrically by measuring absorbance at $535 \mathrm{~nm}$. Higher the absorbance higher will be the concentration of peroxides formed during the reaction, consequently lower will the antioxidant activity. According to Sultana et al. [39] methanolic extracts of T. arjuna showed $44.4 \%$ inhibition at $200 \mu \mathrm{g} / \mathrm{ml}$ concentration which was much lower than our tested extracts.

The RP of a compound acts as an indicator of its potential antioxidant activity [40]. In the RP assay, the presence of antioxidants in the samples would result in the reduction of $\mathrm{Fe}^{3+}$ to $\mathrm{Fe}^{2+}$ by donating an electron. The amount of $\mathrm{Fe}^{3+}$ reduction can be then monitored by measuring the formation of $\left(\mathrm{Fe}^{3+}\right)_{4}\left[\mathrm{Fe}^{2+}(\mathrm{CN})_{6}\right]_{3}$ complex (pearl's Prussian blue) at $700 \mathrm{~nm}$ indicates an increase in reductive ability [41]. $\mathrm{Fe}^{3+}$ reduction is often used as a significant indicator of electron-donating activity which is an important mechanism of phenolic antioxidant action [42]. The methanolic extracts showed highest activity than aqueous extracts in a dose- 
dependant manner, which is due to the presence of these phenolic compounds.

It was observed that the FRSA of the methanolic and aqueous extracts was positively correlated with their total amount of phenolic compounds $\left(\mathrm{R}^{2}=0.977\right.$ and $\left.\mathrm{R}^{2}=0.943\right)$. Many studies in the literature present positive correlations between the quantity of phenolic compounds and the DPPH scavenging effect $[43,44]$. In our study as well, a positive correlation was observed between the antioxidant activities and the composition of total phenolics.

\section{CONCLUSION}

The results of the present study revealed that TB possessed potent free radical scavenging ability in methanolic and aqueous extracts. In all the antioxidant assays performed, the methanolic extract was found to be a more potent radical scavenger compared to that of aqueous extracts. The activity observed may be attributed to the presence of more phenolic contents in the methanolic extract and further we conclude that methanolic extracts of TB are potential candidates for natural antioxidants in food and pharmaceutical industries.

\section{ACKNOWLEDGMENT}

Rasna Gupta is grateful to Head, Department of Biochemistry, RML Avadh University for providing laboratory facilities.

\section{AUTHORS CONTRIBUTIONS}

All the author have contributed equally.

\section{CONFLICT OF INTERESTS}

The authors declare no conflict of interest

\section{REFERENCES}

1. Reuter S, Gupta SC, Chaturvedi MM, Aggarwal BB. Oxidative stress, inflammation, and cancer: how are they linked? Free Radical Biol Med 2010;49:1603-16.

2. Balmus IM, Ciobica A, Trifan A, Stanciu C. The implications of oxidative stress and antioxidant therapies in inflammatory bowel disease: clinical aspects and animal models. Saudi J Gastroenterol 2016;22:3-17.

3. Yazdanparast R, Ardestani AJ. In vitro antioxidant and free radical scavenging activity of Cyperus rotundus. Med Food 2007;10:667-74.

4. Yazdanparast R, Bahramikias S, Ardestani A. Nasturtium officinale reduces oxidative stress and enhances antioxidant capacity in hypercholesterolaemic rats. Chem Biol Interact 2008;172:176-84

5. Rashed K, Potocnjak I, Giacometti J. Terminalia bellerica aerial parts ethyl acetate extract exhibits antioxidant, antiinflammatory and anti-fibrotic activity in carbon tetrachloride intoxicated mice. J Funct Foods 2014;8:319-30.

6. Saraphanchotiwitthaya A, Ingkaninan K. Immunomodulatory activity of an acetone extract of Terminalia bellerica Roxb fruit on the mouse immune response in vitro. Int J Pharm Pharm Sci 2014;6:274-8.

7. Ghate NB, Hazra B, Sarkar R, Chaudhuri D, Mandal N. Alteration of bax/bcl-2 ratio contributes to Terminalia bellerica induced apoptosis in human lung and breast carcinoma. In Vitro Cell Dev Biol Anim 2014;50:527-37.

8. Gupta R, Gupta A, Singh RL. Hepatoprotective activities of triphala and its constituents. Int J Pharm Sci Rev Res 2015;4:34-55.

9. Singh RL, Gupta R, Dwivedi N. A review on anti-microbial activities of Triphala and its constituents. World J Pharm Pharm Sci 2016;5:535-58.

10. Gupta R, Singh RL, Dwivedi N. In vitro antioxidant activity and GC-MS analysis of ethanolic extracts of Terminalia bellerica RoxB (Baheda). Int J Pharm Pharm Sci 2016;8:1-8.

11. Pandey KB, Rizvi SI. Plant polyphenols as dietary antioxidants in human health and disease. Oxid Med Cell Longev 2009;2:270-8.

12. Ragazzi E, Veronese G. Quantitative analysis of phenolic compounds after thin-layer chromatographic separation. J Chromatogr 1973;77:369-75.
13. Yen GC, Duh PD. Scavenging effect of methanolic extracts of peanut hulls on free radical and active oxygen. J Agric Food Chem 1994;42:629-32.

14. Nishikimi MN, Rao A, Yagi K. The occurrence of superoxide anion in the reaction of reduced phenazine methosulphate and molecular oxygen. Biochem Biophys Res Commun 1972;46:849-64.

15. Apati P, Szentmihalyi K, Kristo ST. Herbal remedies of Solidagocorrelation of phytochemical characteristics and antioxidative properties. J Pharm Biomed Anal 2003;32:1045-53.

16. Ohkaowa $\mathrm{H}$, Ohisi N, Yagi K, Assay for lipid peroxides in animal tissues by the thiobarbituric acid reaction. Anal Biochem Anal Biochem 1979;95:351-8.

17. Halliwell B, Gutteridge JMC, Aruoma OI. The deoxyribose method: a simple test tube assay for the determination of rate constants for the reaction of hydroxyl radicals. Anal Biochem 1987;165:215-9.

18. Tsuda T, Watanabe M, Ohshima K, Yamamoto A, Kawakishi S, Osawa T. Antioxidative components isolated from the seed of tamarind (Tamarindus indica L.). J Agric Food Chem 1994;42:2671-4.

19. Singh BN, Singh BR, Singh RL. Polyphenolics from various extracts/fractions of red onion (Allium cepa) peel with potent antioxidant and antimutagenic activities. Food Chem Toxicol 2009;47:1109-16.

20. Das NP, Pereira TA. Effects of flavonoids on thermal autooxidation of palm oil: Structure-activity relationship. $[\vec{J} \mathrm{Am}$ Oil Chem Soc 1990;67:255-8.

21. De Gaulejac NSC, Glories Y, Vivas N. Free radical scavenging effect of anthocyanins in red wines. Food Res Int 1999;32:327-33.

22. Shahriar M, Hossain MI, Bahar ANM, Akhter S, Haque MA, Bhuiyan MA. Evaluation of in vitro antioxidant activity of bark extracts of Terminalia arjuna. J Appl Pharm Sci 2012;2:65-8.

23. Venkatesan A, Kathirvel A, Prakash S, Sujatha V. Antioxidant, antibacterial activities and identification of bioactive compounds from Terminalia chebula bark extracts. Free Radicals Antioxid 2017;7:43-9.

24. Shimada K, Fujikawa K, Yahara K, Nakamura T. Antioxidative properties of xanthan on the autoxidation of soybean oil in cyclodextrin emulsion. J Agric Food Chem 1992;40:945-8.

25. Fukumoto LR, Mazza G. Assessing antioxidant and prooxidant activities of phenolic compounds. J Agric Food Chem 2000;48:3597-604.

26. Soares JR, Dins TCP, Cunha AP, Almeida LM. Antioxidant activities of some extracts of Thymus zygis. Free Radical Res 1997;26:469-78.

27. Guo XY, Wang J, Wang NL, Kitanaka S, Yao XS. 9, 10Dihydrophenanthrene derivatives from Pholidota yunnanensis and scavenging activity on DPPH free radical. J Asian Nat Prod Res 2007;9:165-74.

28. Halliwell B, Gutteridge JMC. Oxygen toxicity, oxygen radicals, transition metals, and disease. Biochem J 1984;219:1-14.

29. Wickens AP. Ageing and the free radical theory. Respir Physiol 2001;128:379-91.

30. Liu F, Ooi VEC, Chang ST. Free radical scavenging activities of mushroom polysaccharide extracts. Life Sci 1997;60:763-71.

31. Pietta PG. Flavonoids as antioxidants. J Nat Prod 2000;63:103542.

32. Cos P, Ying L, Calomme M. Structure-activity relationship and classification of flavonoids as inhibitors of xanthine oxidase and superoxide scavengers. J Nat Prod 1998;61:71-6.

33. Parejo I, Viladomat F, Bastida J. Comparison between the radical scavenging activity and antioxidant activity of six distilled and undistilled mediterranean herbs and aromatic plants. J Agric Food Chem 2002;50:6882-90.

34. Shahidi F. Natural antioxidants, chemistry, health effects and applications. IL, USA: AOCS Press Champaign; 1997.

35. Sherin L, Mustafa M, Shujaat S. Evaluation of Terminalia bellerica roxb. leaf extracted in different solvents for antioxidant activities. Asian J Chem 2015;27:4527-31.

36. Spencer JPE, Jenner A, Aruoma OI. Intense oxidative DNA damage promoted by L-Dopa and its metabolites, implications for neurodegenerative disease. FEBS Lett 1994;353:246-50.

37. Marnett LJ. Lipid peroxidation-DNA damage by malondialdehyde. Mutat Res 1999;424:83-95. 
38. Yen GC, Duh PD, Chuang DY. Antioxidant activity of anthraquinones and anthrone. Food Chem 2000;70:307-15.

39. Sultana B, Anwar F, Przybylski R. Antioxidant activity of phenolic components present in barks of Azadirachta indica, Terminalia arjuna, Acacia nilotica, and Eugenia jambolana Lam. trees. Food Chem 2007;104:1106-14.

40. Meir S, Kanner J, Akiri B, Hadas SP. Determination and involvement of aqueous reducing compounds in oxidative defense systems of various senescing leaves. J Agric Food Chem 1995;43:1813-7.

41. Djeridane A, Yousfi M, Nadjemi B, Boutassouna D, Stocker P, Vidal N. Antioxidant activity of some algerian medicinal plants extracts containing phenolic compounds. Food Chem 2006;97:654-60.

42. Nabavi SM, Ebrahimzadeh MA, Nabavi SF, Bahramian F. In vitro antioxidant activity of phytolacca americana berries. Pharmacologyonline 2009;1:81-8.

43. Kedare SB, Singh RP. Genesis and development of DPPH method of antioxidant assay. J Food Sci Technol 2011;48:412-22.

44. Liu SC, Lin JT, Wang CK, Chen HY, Yang DJ. Antioxidant properties of the various solvent extract from lychee (Litchi chinenesis Sonn.) flowers. Food Chem 2009;114:577-81. 